\title{
Research reactor claims agreement on uranium fuel
}

Munich. A controversial research reactor planned by the Technical University of Munich in Garching seems certain to be built after a decision by the Wissenschaftsrat, Germany's science council, to recommend that the federal government pays half of the DM665 million ( $\$ 445$ million) costs.

The decision has been welcomed by the university, which told the Wissenschaftsrat that it had been guaranteed 400 kilograms of highly enriched uranium (HEU) enough to run the reactor for ten years from the French company Cerka. The supplies have been obtained through the European Union's Euratom Supply Agency, which claims that they come from non-military sources in western Europe.

The Green party and the opposition Social Democrats, both of which have campaigned against the research reactor known as FRMII - are concerned that the reactor will burn weapons-grade HEU. They point out that the decision to build the reactor may be in conflict with an international agreement reached in 1978, the RERTR, (Reduced Enrichment for Research and Test Reactors), that research reactors should convert to low-enriched uranium, in order to eliminate trade in bomb-grade plutonium for civilian use.

The United States has refused to supply fuel to the FMRII, leading to a search for other suppliers. Many believe that the supplies now agreed will come from HEU that has been separated at the Dounreay reprocessing plant in Scotland from unused fuel elements originally manufactured for the high-temperature reactor (THTR-300) in northwestern Germany, which was abandoned shortly after starting up in 1985.

The Wissenschaftsrat said last week it saw no scientific reason to reverse its recommendation, made in 1989, to build a new national neutron source and believed that the FRMII met the necessary criteria.

The production, transport and use of the HEU will be under the joint control of Euratom and the International Atomic Energy Agency (IAEA). The university says that there is therefore no danger that it could be used to create nuclear weapons.

It also says that it has an agreement that spent fuel will be stored at an interim storage site in Ahaus, in northern Germany, for up to 40 years. A decision on long-term storage cannot be made until Germany makes up its mind on the long-term storage of radioactive waste in general.

The final hurdles facing the FRMII are the need to obtain a licence to use nuclear material, and clearance from the local environment ministry. Both are expected by the end of the year.

Alison Abbott

\section{Berlin university protests at bid to cut science faculties}

Munich. East Berlin's Humboldt University has reacted angrily to a suggestion that it shoulder more than half of a DM47 million ( $\$ 33$ million) cut being imposed by the city on its three universities as a result of its rapidly deteriorating finances.

The university, one of the principal scientific institutions in Germany before the Second World War, is also upset at a suggestion by the city's science minister, Manfred Erhardt, that it should absorb the cut by reducing its natural sciences faculties.

A meeting of the university's academic senate held last week formally rejected Erhardt's suggestion, agreeing only to cuts of DM11 million - a sum it feels would not damage individual faculties. The senate said it would take two years to decide where further cuts could be made.

But Humboldt's stand has brought it into direct conflict with the city's other two universities - the Free University, founded in the early $1950 \mathrm{~s}$, and the Technical University - which feel that the Humboldt has already benefitted substantially from reunification.

After the fall of the Berlin wall in 1989, the city, burdened with the costs of rebuilding its eastern sector but deprived of its generous subsidy from Bonn, soon found that it could not afford to run all three institutions. A plan aimed at reducing overlap by merging or closing faculties was approved by the parliament earlier this year after two years of bitter debate. This will save DM130 million in the combined universities' budgets over the next eight years, and reduce the number of students from 115,000 to 100,000 .

Most of the reductions will be borne by the Free University, which will have to make cuts of nearly DM75 million. In contrast, the budget plans of the Humboldt University, which has already had to shed 3,500 staff during the reunification process, was left intact. But, in the light of the city's worsening financial crisis, the Berlin government has now asked the university for a further saving of DM45 million.

This time, Erhardt has decided that Humboldt University should take the lion's share of the cuts. Referring to a review carried out by the Wissenschaftsrat, Germany's science council, he has suggested the university's pharmacy faculty should be closed, and that other natural sciences fac- ulties be reduced in size.

Konrad Seppelt, vice-president for science and research at the Free University, backs Erhardt's decision. "The Humboldt University has had enormous financial investment in medicine and the humanities [since reunification]", he says, "so natural science can never be a priority for it". By 